\title{
Short communication: Technological and seasonal variations of vitamin $D$ and other nutritional components in donkey milk
}

\author{
Mina Martini, ${ }^{*} \dagger$ lolanda Altomonte, ${ }^{*}$ Rosario Licitra, ${ }^{*}$ and Federica Salari ${ }^{* 1}$ \\ *Dipartimento di Scienze Veterinarie, and \\ †Centro Interdipartimentale di Ricerca Nutraceutica e Alimentazione per la Salute, Università di Pisa, Italy 56121
}

\begin{abstract}
Vitamin D is an essential nutrient that plays a crucial role in calcium homeostasis and bone metabolism and also acts as a hormone. Although several studies on the content of vitamin $\mathrm{D}$ in bovine milk have been conducted, little information is available regarding donkey milk. In the context of the nutritional assessment of donkey milk, the aim of this study was to assess the vitamin $\mathrm{D}$ content in donkey milk and its chemical profile, with particular reference to seasonal and technological modifications after pasteurization. The study was conducted on a dairy farm that produces donkey milk for human consumption located in central Italy. At sampling time, an aliquot of total bulk milk production was sampled before and after pasteurization $\left(63^{\circ} \mathrm{C}\right.$ for 30 min without homogenization) with a total of 20 raw and 20 pasteurized milk samples. The samples were collected for 10 mo, every 15 d, from May to February 2017. All the samples were analyzed for the chemical composition and vitamin $\mathrm{D}_{2}$ and $\mathrm{D}_{3}$ content by HPLC after saponification. The donkey milk analyzed showed a higher average vitamin $\mathrm{D}$ content (raw milk: vitamin $\mathrm{D}_{2}=1.68$, vitamin $\mathrm{D}_{3}=0.60 \mu \mathrm{g} / 100 \mathrm{~mL}$; pasteurized milk: vitamin $\mathrm{D}_{2}=1.38$, vitamin $\mathrm{D}_{3}=0.30 \mu \mathrm{g} / 100$ $\mathrm{mL}$ ) than reported for bovine and human milk. The results of the effect of pasteurization on milk did not highlight significant differences in the total content of vitamin $\mathrm{D}$. However, vitamin $\mathrm{D}_{3}$ has a poor thermal stability, which led to a significant reduction in content in pasteurized milk compared with raw milk. The total vitamin $\mathrm{D}$ content of donkey milk did not show significant variations between seasons; however, a higher concentration of vitamin $\mathrm{D}_{3}$ was found in spring and summer. In conclusion, raw and pasteurized donkey milk showed a high content of vitamin $\mathrm{D}$, which could be useful in meeting the deficiencies of this vitamin in
\end{abstract}

Received March 20, 2018.

Accepted June 6, 2018.

${ }^{1}$ Corresponding author: federica.salari@unipi.it humans. Further investigations are needed to improve the vitamin $\mathrm{D}$ content in donkey milk by increasing its endogenous synthesis or its transfer in milk and to clarify other variability factors.

Key words: donkey milk, vitamin D, seasonal variability, pasteurization

\section{Short Communication}

Vitamin D plays a key role in calcium homeostasis and bone metabolism and acts as a hormone (Müller et al., 2011). Vitamin $\mathrm{D}_{2}$ (ergocalciferol) is derived from the UV radiation of ergosterol (in particular UV-B radiation), which is a vitamin $\mathrm{D}$ precursor naturally found in plants, fungi, and invertebrates. Vitamin $\mathrm{D}_{3}$ (cholecalciferol) is derived by sunlight exposure from 7-dehydrocholesterol, which is a precursor of cholesterol and also acts as a provitamin $\mathrm{D}_{3}$ (Schmid and Walther, 2013).

The major source of vitamin D for children and adults is exposure to natural sunlight that is required for UV-B-induced vitamin D production in the skin. Vitamin D that comes from the skin or diet is biologically inert and requires its first hydroxylation in the liver to $25(\mathrm{OH}) \mathrm{D}_{3}$. The latter requires a further hydroxylation in the kidneys to form the biologically active form of vitamin $\mathrm{D} 1,25(\mathrm{OH})_{2} \mathrm{D}$.

An oral intake of vitamin D may be an important source in winter, when the UV-B-related synthesis is limited and for people who are not exposed to sunlight (Gill et al., 2016). Vitamin D deficiency is well known, and the concentration in blood serum of the hydroxylated form of calciferol $\left[25(\mathrm{OH}) \mathrm{D}_{3}\right]$ is recognized as a sensitive accurate indicator of the functional status of vitamin D (Heaney, 2004). The Institute of Medicine (IOM, 2011) defined a vitamin D deficiency as a content of $25(\mathrm{OH}) \mathrm{D}_{3}$ less than $20 \mathrm{ng} / \mathrm{mL}$ in serum. In addition, the widespread risk of deficiency and insufficiency worldwide has been reported (Holick et al., 2011), due to the current mostly indoor life style. In Italy, vitamin $\mathrm{D}$ deficiency and insufficiency were detected in 49.9 and $32.3 \%$ of adolescents, respectively, and $8.9 \%$ of Italian 
adolescents were severely deficient (Vierucci et al., 2014).

Vitamin D dietary intake is also of great importance, and animal foodstuffs (e.g., fish, meat, offal, eggs, and dairy) are the main sources for naturally occurring cholecalciferol (vitamin $\mathrm{D}_{3}$ ). However, it is difficult to cover the requirements of vitamin D solely by foodstuffs (Schmid and Walther, 2013). Milk mainly contains 2 forms of vitamin $\mathrm{D}\left(\mathrm{D}_{3}\right.$ and $\left.\mathrm{D}_{2}\right)$.

Research has highlighted the variability factors of vitamin $\mathrm{D}$ in milk by analyzing endogenous, exogenous, and technological factors, such as season, age of the animal, treatment, and conservation (Jakobsen and Saxholt, 2009; Weir et al., 2017). However, most of the studies focus on bovine milk, whereas little information regarding donkey milk is available (Gentili et al., 2013; Bulgari et al., 2015). The properties of donkey milk have been known since ancient times, and in the last few decades there has been renewed interest from the scientific community due to donkey milk's use as a therapeutic product for children with bovine milk protein allergy (Martini et al., 2017).

Despite having a low bacterial count, the thermal treatment of donkey raw milk is recommended to avoid the risk of food-borne diseases (Martini et al., 2016). Pasteurization is known to eliminate pathogenic microorganisms that could be present in milk and guarantees its preservation. Furthermore, the literature on the effects of pasteurization on nutritional characteristics of donkey milk is not yet exhaustive. In addition, unlike cow milk that is mostly standardized, donkey milk has a certain variability in terms of its components.

Nutritional characteristics of donkey milk are especially interesting, as this milk is targeted for consumption by children for its similarity to human milk. In addition, consumption in the elderly has been proposed given that donkey milk has good calcium content, is low in fat, and easily digestible. Children and the elderly are at particular risk for developing nutritional deficiencies; therefore, they require careful nutrition management, from a quantitative and qualitative point of view, to avoid undernourishment and malnutrition. In the context of the nutritional assessment of donkey milk, the aim of our paper was to carry out an evaluation of the vitamin $\mathrm{D}$ content in donkey milk and its chemical profile, with particular reference to seasonal and technological modifications after pasteurization.

The study was conducted on dairy farm that produces donkey milk for human consumption. The farm, located in central Italy, raised about 160 Amiata donkeys, reared outdoors, in a semi-intensive system. The animals were fed about $2.5 \mathrm{~kg} / \mathrm{d}$ per head of concentrate for dairy donkeys (Progeo S.C.A., Masone, Italy) and polyphite hay ad libitum. The jennies were routinely machine milked twice a day.

At sampling time, an aliquot of total daily bulk milk production was sampled before and after pasteurization $\left(63^{\circ} \mathrm{C}\right.$ for $30 \mathrm{~min}$ without homogenization). The samples were collected for 10 mo, every $15 \mathrm{~d}$, from May to February 2017 (20 raw and 20 pasteurized milk samples), for a total of 40 samples.

All the samples were analyzed for DM, fat, and lactose content by infrared analysis (Milkoscan, Italian Foss Electric, Padova, Italy) as well as protein, casein, and ash (AOAC International, 2006). Individual mineral content $(\mathrm{Ca}, \mathrm{P}, \mathrm{Mg}, \mathrm{K}, \mathrm{Na}$, and $\mathrm{Zn} ; \mathrm{mg} / \mathrm{L})$ was determined by atomic absorption spectroscopy and UV-visible spectroscopy according to Horwitz (2000) and Murthy and Rhea (1967). Milk fat extraction was performed following the Röse-Gottlieb method (933.05, AOAC International, 1995), and FAME were prepared using methanolic sodium methoxide according to Christie (1982). A Perkin Elmer Clarus 480 (Perkin Elmer, Norwolk, CT) equipped with a flame ionization detector and a capillary column $(60 \mathrm{~m} \times 0.25 \mathrm{~mm}$; film thickness $0.25 \mathrm{~mm}$; ThermoScientific TR-FAME $60 \mathrm{~m}$ $\times 0.25 \mathrm{~mm}$ ID; film thickness $0.25 \mu \mathrm{m}$, Thermo Fisher Scientific, Waltham, MA) were used.

The helium carrier gas flow rate was $1 \mathrm{~mL} / \mathrm{min}$. The oven temperature program level 1 was $50^{\circ} \mathrm{C}$ held for 5 min; level 2 was 50 to $140^{\circ} \mathrm{C}$ at $3^{\circ} \mathrm{C} / \mathrm{min}$, then held for $2 \mathrm{~min}$; and level 3 was 140 to $240^{\circ} \mathrm{C}$ at $1^{\circ} \mathrm{C} / \mathrm{min}$, then held for $10 \mathrm{~min}$. The injector and detector temperatures were set at 270 and $300^{\circ} \mathrm{C}$, respectively. The peak areas of individual fatty acids (FA) were identified using an FA standard injection (Food Industry FAME Mix Restek Corporation, Bellefonte, PA) and quantified as the percentage of total FA. In addition, nonadecanoic acid methyl ester (C19:0, Restek Corporation) was also used as an internal standard.

Milk fatty acids were grouped as SFA, MUFA, PUFA, and short-chain (SCFA), medium-chain (MCFA), and long-chain fatty acids (LCFA). The SFA included इC4:0, C6:0, C8:0, C10:0, C11:0, C12:0, C13:0, C14:0, C15:0, C16:0, C17:0, C18:0, C20:0, C21:0, C22:0, C23:0, and C24:0. The MUFA included $\Sigma$ C14:1, C15:1, C16:1, C17:1, C18:1 trans-9, C18:1 trans-11, C18:1 cis-9, C20:1, C22:1, and C24:1. The PUFA included $\Sigma$ C18:2 trans-9,12, C18:2 cis-9,12, C18:3n-6, C18:3n-3, C20:2, C20:3n-6, C20:4, C20:3n-3, C20:5, C22:2, C22:5, and $\mathrm{C} 22: 6$. The SCFA included the sum of FA from 4 to 10 C, MCFA included the sum of FA from 11 to $17 \mathrm{C}$, and LCFA included the sum of FA from 18 to $24 \mathrm{C}$.

For the determination of vitamin $\mathrm{D}, 75 \mathrm{~mL}$ of donkey milk was saponified by adding $\mathrm{KOH}$ pellets directly to the milk according to Perales et al. (2005). As a 
Table 1. Effects of pasteurization $\left(63^{\circ} \mathrm{C}\right.$ for $\left.30 \mathrm{~min}\right)$ on nutritional characteristics and vitamin $\mathrm{D}$ content of donkey milk $(\mathrm{n}=40)^{1}$

\begin{tabular}{|c|c|c|c|c|}
\hline Item & Raw milk & $\mathrm{SE}$ & Pasteurized milk & SE \\
\hline Fat, $\%$ & 0.15 & 0.021 & 0.15 & 0.022 \\
\hline Protein, \% & 1.64 & 0.054 & 1.58 & 0.057 \\
\hline DM, \% & 9.30 & 0.070 & 9.28 & 0.074 \\
\hline Ash, $\%$ & 0.37 & 0.008 & 0.36 & 0.008 \\
\hline $\mathrm{Ca}, \mathrm{mg} / \mathrm{L}$ & 647.25 & 49.969 & 674.69 & 47.314 \\
\hline $\mathrm{P}, \mathrm{mg} / \mathrm{L}$ & 375.11 & 21.682 & 390.70 & 20.530 \\
\hline $\mathrm{Mg}, \mathrm{mg} / \mathrm{L}$ & 101.31 & 10.740 & 101.72 & 10.167 \\
\hline $\mathrm{K}, \mathrm{mg} / \mathrm{L}$ & 652.88 & 29.193 & 626.75 & 27.642 \\
\hline $\mathrm{Na}, \mathrm{mg} / \mathrm{L}$ & 202.25 & 34.677 & 176.69 & 32.835 \\
\hline $\mathrm{Zn}, \mathrm{mg} / \mathrm{L}$ & 2.88 & 0.560 & 3.28 & 0.530 \\
\hline SCFA, \% & 11.79 & 0.472 & 11.96 & 0.499 \\
\hline MCFA, $\%$ & 42.60 & 0.877 & 41.61 & 0.927 \\
\hline LCFA, \% & 45.61 & 1.049 & 46.43 & 1.109 \\
\hline SFA, $\%$ & 51.70 & 1.135 & 50.75 & 1.200 \\
\hline MUFA, $\%$ & 28.56 & 0.773 & 29.29 & 0.818 \\
\hline PUFA, \% & 19.74 & 0.729 & 19.97 & 0.771 \\
\hline UFA/SFA & 0.94 & 0.035 & 0.98 & 0.037 \\
\hline n-3/n-6 & 0.69 & 0.082 & 0.73 & 0.087 \\
\hline Total vitamin $\mathrm{D}, \mu \mathrm{g} / 100 \mathrm{~mL}$ & 2.23 & 0.240 & 1.68 & 0.253 \\
\hline Vitamin $D_{2}, \mu \mathrm{g} / 100 \mathrm{~mL}$ & 1.64 & 0.211 & 1.38 & 0.223 \\
\hline Vitamin $\mathrm{D}_{3}, \mu \mathrm{g} / 100 \mathrm{~mL}$ & $0.60^{\mathrm{a}}$ & 0.127 & $0.30^{\mathrm{b}}$ & 0.134 \\
\hline
\end{tabular}

$\overline{\mathrm{a}, \mathrm{b}}$ Means within a row with different superscripts differ $(P \leq 0.05)$.

${ }^{1} \mathrm{SCFA}=$ short-chain fatty acids; MCFA = medium-chain fatty acids; LCFA = long-chain fatty acids.

high temperature may lead to the isomerization of $\mathrm{D}$ vitamins, saponification occurred at $40^{\circ} \mathrm{C}$ for $32 \mathrm{~min}$. Ethanol and double-distilled water were then added to the sample to remove the polar compounds and to avoid foaming. Afterward, the solution was transferred to a 500-mL separatory funnel, and an initial extraction of the unsaponifiable fraction was performed using $75 \mathrm{~mL}$ of hexane. The aqueous phase was thus drained and collected to repeat 2 extractions by adding $75 \mathrm{~mL}$ of hexane each time. Each time, the organic phase was collected in a rotary evaporator flask. Finally, the organic phase was evaporated to dryness on a rotary evaporator and the extract was resuspended in $500 \mu \mathrm{L}$ of acetonitrile and filtered through a $0.45-\mu \mathrm{m}$ diameter syringe filter. One hundred microliters of the extract was injected into an HPLC and isocratically eluted using as a mobile phase acetonitrile-methanol 97:3 at a flow of $1 \mathrm{~mL} / \mathrm{min}$, as described by Hagar et al. (1994). A Kinetex core-shell column (Phenomenex Inc., Torrance, $\mathrm{CA}$ ) was used as the stationary phase and the UV detector was set at $254 \mathrm{~nm}$. Vitamins $\mathrm{D}_{2}$ and $\mathrm{D}_{3}$ in the milk samples were quantified by comparison with a calibration curve obtained with the injection of the pure standards (Sigma-Aldrich, St. Louis).

All the results were analyzed by ANOVA, where season (autumn-winter or spring-summer) and thermal treatment (raw or pasteurized milk) were the fixed effects. Significant differences were considered at $P \leq$ 0.05 . The statistical analysis was carried out using JMP (2007) software.
The donkey milk analyzed showed a higher average vitamin $\mathrm{D}$ content (raw milk: vitamin $\mathrm{D}_{2}=1.68$, vitamin $\mathrm{D}_{3}=0.60 \mu \mathrm{g} / 100 \mathrm{~mL}$; pasteurized milk: vitamin $\mathrm{D}_{2}$ $=1.38$, vitamin $\mathrm{D}_{3}=0.30 \mu \mathrm{g} / 100 \mathrm{~mL}$ ) than reported for bovine and human milk (Zhang et al., 2012; Schmid and Walther 2013). Our results shows that the main vitamin $\mathrm{D}$ form present in donkey milk was vitamin $\mathrm{D}_{2}$.

The results related to the effect of heat treatment on milk (Table 1) did not highlight significant differences in the chemical composition either in relation to the total content of vitamin D or in the main constituents of milk and FA classes. Our results therefore indicate that pasteurization treatment at $63^{\circ} \mathrm{C}$ does not involve substantial changes to the quality of the milk, similar to results from other authors (Addo and Ferragut 2015; Martini et al., 2016).

As reported by Tsai et al. (2017), vitamin $\mathrm{D}_{3}$ has poor thermal stability, which results in a significant reduction $(P \leq 0.05)$ of about $50 \%$ of vitamin $\mathrm{D}_{3}$ in pasteurized milk compared with raw milk (Table 1 ). Despite the strong decrease in the vitamin $\mathrm{D}_{3}$ content, the total vitamin $\mathrm{D}$ amount was only partially affected. In fact, the total vitamin $D$ decreased but not significantly. This can be attributed to the large contribution of vitamin $\mathrm{D}_{2}$, which has been described as heat-stable both after pasteurization at $63^{\circ} \mathrm{C}$ for $30 \mathrm{~min}$ and after sterilization (Kaushik et al., 2014).

Seasonal variations in donkey milk quality were found (Table 2). In particular, DM content and several mineral salts, such as phosphorus and zinc, were signifi- 
Table 2. Effects of the season on the nutritional characteristics and vitamin D content of donkey milk $(\mathrm{n}=$ $40)^{1}$

\begin{tabular}{|c|c|c|c|c|}
\hline Item & Autumn/winter & SE & Spring/summer & SE \\
\hline Fat, $\%$ & 0.14 & 0.020 & 0.16 & 0.018 \\
\hline Protein, \% & 1.57 & 0.048 & 1.64 & 0.042 \\
\hline DM, \% & $9.09^{\mathrm{b}}$ & 0.079 & $9.46^{\mathrm{a}}$ & 0.070 \\
\hline Ash, $\%$ & 0.37 & 0.008 & 0.36 & 0.007 \\
\hline $\mathrm{Ca}, \mathrm{mg} / \mathrm{L}$ & 603.36 & 53.706 & 699.38 & 44.015 \\
\hline $\mathrm{P}, \mathrm{mg} / \mathrm{L}$ & $354.02^{\mathrm{b}}$ & 23.304 & $402.17^{\mathrm{a}}$ & 19.098 \\
\hline $\mathrm{Mg}, \mathrm{mg} / \mathrm{L}$ & 90.71 & 11.541 & 108.75 & 9.458 \\
\hline $\mathrm{K}, \mathrm{mg} / \mathrm{L}$ & 675.24 & 31.376 & 616.20 & 25.714 \\
\hline $\mathrm{Na}, \mathrm{mg} / \mathrm{L}$ & 164.22 & 37.270 & 208.81 & 30.545 \\
\hline $\mathrm{Zn}, \mathrm{mg} / \mathrm{L}$ & $2.16^{\mathrm{b}}$ & 0.601 & $3.69^{\mathrm{a}}$ & 0.493 \\
\hline SCFA, \% & 12.20 & 0.422 & 11.60 & 0.374 \\
\hline MCFA, \% & 41.63 & 0.805 & 42.52 & 0.712 \\
\hline LCFA, \% & 46.16 & 0.960 & 45.88 & 0.849 \\
\hline SFA, $\%$ & 50.77 & 1.032 & 51.61 & 0.913 \\
\hline MUFA, \% & $30.57^{\mathrm{A}}$ & 0.734 & $27.60^{\mathrm{B}}$ & 0.650 \\
\hline PUFA, \% & $18.66^{\mathrm{b}}$ & 0.680 & $20.78^{\mathrm{a}}$ & 0.601 \\
\hline UFA/SFA & 0.98 & 0.038 & 0.94 & 0.033 \\
\hline $\mathrm{n}-3 / \mathrm{n}-6$ & $0.54^{\mathrm{B}}$ & 0.083 & $0.84^{\mathrm{A}}$ & 0.074 \\
\hline Total vitamin $\mathrm{D}, \mu \mathrm{g} / 100 \mathrm{~mL}$ & 1.65 & 0.250 & 2.21 & 0.240 \\
\hline Vitamin $\mathrm{D}_{2}, \mu \mathrm{g} / 100 \mathrm{~mL}$ & 1.49 & 0.224 & 1.53 & 0.210 \\
\hline Vitamin $\mathrm{D}_{3}, \mu \mathrm{g} / 100 \mathrm{~mL}$ & $0.16^{\mathrm{B}}$ & 0.133 & $0.68^{\mathrm{A}}$ & 0.127 \\
\hline
\end{tabular}

$\overline{\mathrm{a}, \mathrm{b}}$ Means within a row with different superscripts differ $(P \leq 0.05)$.

${ }^{\mathrm{A}, \mathrm{B}}$ Means within a row with different superscripts differ $(P \leq 0.01)$.

${ }^{1} \mathrm{SCFA}=$ short-chain fatty acids; MCFA = medium-chain fatty acids; LCFA = long-chain fatty acids.

cantly $(P \leq 0.05)$ higher in the spring and summer season. These findings are supported by a previous study by Martini et al. (2014), in which seasonal changes in milk quality were found and were suggested as being the result of the better adaptability of the Amiatina donkey to a warm and temperate climate.

In addition, significant differences in the FA classes were recorded, in particular regarding UFA. In fact, in the spring and summer season, we found a significantly lower content of MUFA $(P \leq 0.01)$ and higher content of PUFA $(P \leq 0.05)$ and n-3/n-6 ratio $(P \leq 0.01)$, and therefore a greater incidence of n-3 on the total PUFA.

In vitro studies have found that the vitamin D-binding protein, the main carrier of vitamin $\mathrm{D}$ in blood and milk, competitively binds some MUFA (Williams et al., 1988; Calvo and Ena, 1989), such as C18:1 cis-9, which is one of the main MUFA in donkey milk (Martini et al., 2015). Although other factors may be involved in the decrease in the synthesis of MUFA in summer milk, competition for the carrier protein due to the increase in vitamin $\mathrm{D}$ secretion may to some extent contribute to the decrease in this family of FA in milk. However, this hypothesis needs further investigation.

In donkey milk, the total vitamin $\mathrm{D}$ content did not undergo significant variations; however, a higher $(P \leq$ 0.01 ) concentration of vitamin $\mathrm{D}_{3}$ was found in spring and summer than in autumn and winter, in particular the vitamin $\mathrm{D}_{3}$ content was 4 times higher than in the autumn and winter. This is probably due to the dif- ferent sun exposure of the animals facilitated by the outdoor farming system. Seasonal variations in vitamin D content of milk have been well documented in cows, with higher concentrations in the summer months than in the winter (Jakobsen and Saxholt, 2009; Weir et al., 2017)

In conclusion, raw and pasteurized donkey milk showed a high content of vitamin D. Although donkey milk is a niche product, the interest of our results derives from its use in consumers at risk of nutritional deficiencies. In fact, for these categories of people, donkey milk could be helpful (together with appropriate integrations) in meeting deficiencies of vitamin D.

Seasonal variations in vitamin $\mathrm{D}$ content as well as of other milk components were also highlighted, in particular the spring and summer season tends to increase the vitamin $\mathrm{D}_{3}$ concentration in milk. Pasteurization affected the vitamin $\mathrm{D}_{3}$ content, which is more thermolabile than $\mathrm{D}_{2}$, but it did not influence the total vitamin D uptake. Further investigations are needed to improve the vitamin D content in donkey milk through increasing its endogenous synthesis or its transfer in milk and to clarify other variability factors.

\section{ACKNOWLEDGMENTS}

The research was funded by the Regional Government of Tuscany: Bando pubblico per progetti di ricerca nel settore Nutraceutica. L.A.B.A.Pro.V. 


\section{REFERENCES}

Addo, C. N. A., and V. Ferragut. 2015. Evaluating the ultra-high pressure homogenization (UHPH) and Pasteurization effects on the quality and shelf life of donkey milk. Int. J. Food Stud. 4:104-115. https://doi.org/10.7455/ijfs/4.1.2015.a9.

AOAC International. 1995. Official Methods of Analysis. 16th ed. Vol. II. AOAC International, Arlington, VA.

AOAC International. 2006. Official Methods of Analysis. 18th ed. Vol. I. AOAC International, Gaithersburg, VA.

Bulgari, O., A. M. Caroli, S. Chessa, F. Salari, I. Altomonte, S. Savino, M. Martini, and C. Gigliotti. 2015. Confronto tra il contenuto di vitamina D nel latte di differenti specie. Sci. Tecn. Latt. Cas. $66: 45-49$.

Calvo, M., and J. M. Ena. 1989. Relations between vitamin D and fatty acid binding properties of vitamin D-binding protein. Bioehem. Biophys. Res. Commun. 163:14-17.

Christie, W. W. 1982. A simple procedure of rapid transmethylation of glycerolipids and cholesteryl esters. J. Lipid Res. 23:1072-1075.

Gentili, A., F. Caretti, S. Bellante, S. Ventura, S. Canepari, and R. Curini. 2013. Comprehensive profiling of carotenoids and fat-soluble vitamins in milk from different animal species by LC-DADMS/MS hyphenation. J. Agric. Food Chem. 61:1628-1639. https:/ /doi.org/10.1021/jf302811a.

Gill, B. D., X. Zhu, and H. E. Indyk. 2016. The determination of vitamin D3 and 25-hydroxyvitamin D3 in early lactation and seasonal bovine milk. Int. Dairy J. 63:29-34.

Hagar, A. F., L. Madsen, L. Wales, and H. B. Bradfor. 1994. Reversed phase liquid chromatographic determination of vitamin D in milk. J. AOAC Int. 77:1047-1051.

Heaney, R. P. 2004. Functional indices of vitamin D status and ramifications of vitamin D deficiency. Am. J. Clin. Nutr. 80:1706S1709S. https://doi.org/10.1093/ajcn/80.6.1706S.

Holick, M. F., N. C. Binkley, H. A. Bischoff-Ferrari, C. M. Gordon, D. A. Hanley, R. P. Heaney, M. Hassan Murad, and C. M. Weaver 2011. Evaluation, treatment, and prevention of vitamin d deficiency: An endocrine society clinical practice guideline. J. Clin. Endocrinol. Metab. 96:1911-1930.

Horwitz, W., ed. 2000. Official Method of Analysis of AOAC International. 17th ed. AOAC International, Gaithersburg, VA.

IOM (Institute of Medicine). 2011. Dietary Reference Intakes for Calcium and Vitamin D. Natl. Acad. Press, Washington, DC.

Jakobsen, J., and E. Saxholt. 2009. Vitamin D metabolites in bovine milk and butter. J. Food Compos. Anal. 22:472-478.

JMP. 2007. User's Guide, version 7.0. SAS. Inst. Inc., Cary, NC.

Kaushik, R., B. Sachdeva, and S. Arora. 2014. Vitamin D2 stability in milk during processing, packaging and storage. LWT Food Sci. Technol. 56:421-426.
Martini, M., I. Altomonte, R. Licitra, and F. Salari. 2017. Nutritional and nutraceutical quality of donkey milk. J. Equine Vet. Sci. https: //doi.org/10.1016/j.jevs.2017.10.020

Martini, M., I. Altomonte, E. Manica, and F. Salari. 2015. Changes in donkey milk lipids in relation to season and lactation. J. Food Compos. Anal. 41:30-34. https://doi.org/10.1016/j.jfca.2014.12 019 .

Martini, M., I. Altomonte, F. Salari, and A. M. Caroli. 2014. Short communication: Monitoring nutritional quality of Amiata donkey milk: Effects of lactation and productive season. J. Dairy Sci. 97:6819-6822. https://doi.org/10.3168/jds.2014-8544.

Martini, M., F. Salari, I. Altomonte, G. Ragona, D. Casati, and G. Brajon. 2016. Conservazione del latte d'asina: Aspetti nutrizionali e igienico-sanitari. Sci. Tec. Latt.-Casearia 67:63-72.

Müller, D. N., M. Kleinewietfeld, and H. Kvakan. 2011. Vitamin D review. J. Renin Angiotensin Aldosterone Syst. 12:125-128.

Murthy, G. K., and U. Rhea. 1967. Determination of major cations in milk by atomic absorption spectrophotometry. J. Dairy Sci 50:313-317. https://doi.org/10.3168/jds.S0022-0302(67)87416-2.

Perales, S., A. Alegría, R. Barberá, and R. Farré. 2005. Review: Determination of vitamin $\mathrm{D}$ in dairy products by high performance liquid chromatography. Food Sci. Technol. Int. 11:451-462.

Schmid, A., and B. Walther. 2013. Natural vitamin D content in animal products. Adv. Nutr. 4:453-462. https://doi.org/10.3945/an .113 .003780

Tsai, S.-Y., H.-Y. Lin, W.-P. Hong, and C.-P. Lin. 2017. Evaluation of preliminary causes for vitamin D series degradation via DSC and HPLC analyses. J. Therm. Anal. Calorim. 130:1357-1369. https:/ /doi.org/10.1007/s10973-017-6209-4.

Vierucci, F., M. Del Pistoia, M. Fanos, P. Erba, and G. Saggese. 2014. Prevalence of hypovitaminosis D and predictors of vitamin D status in Italian healthy adolescents. Ital. J. Pediatr. 40:54. https:// doi.org/10.1186/1824-7288-40-54

Weir, R. R., J. J. Strain, M. Johnston, C. Lowis, A. M. Fearon, S. Stewart, and L. K. Pourshahidi. 2017. Environmental and genetic factors influence the vitamin D content of cows' milk. Proc. Nutr. Soc. 76:76-82. https://doi.org/10.1017/S0029665116000811.

Williams, M. H., E. L. Van Alstyne, and R. M. Galbraith. 1988. Evidence of a novel association of unsaturated fatty acids with GC (vitamin D-binding protein). Biochem. Biophys. Res. Commun. 153:1019-1024.

Zhang, J. Y., A. J. Lucey, K. Galvin, L. Nolan, K. D. Cashman, J. R. Higgins, and M. Kiely. 2012. Vitamin D content of human milk and associations with milk fat content and maternal serum 25-hydroxyvitamin D concentrations. Proc. Nutr. Soc. 71:E54. https:// doi.org/10.1017/S0029665112001115 